\title{
Religiosity Perceptions and Employee Turnover Intention in Malaysia
}

\author{
Narehan Hassan, Azlyantiny Mohammad, Feridah Mohd, Abdul Aziz Rozilah, and Sharrifah Ali
}

\begin{abstract}
In this study, the researchers analyzed the elements (dimensions) of religious calling as a contributing factor to turnover intention and proposed religiosity to be added as a factor for the theory of employee satisfaction. The study was conducted among employees working at Hypermarkets in the Klang Valley, Selangor, Malaysia. Participants consisted of $\mathbf{1 2 5}$ employees currently working at Hypermarkets (Carefour, Tesco, and Giant) in the Klang Valley, Malaysia. The respondents were conveniently selected and the data were gathered through the distribution of questionnaires. The study found that there was no significant relationship between religious calling and turnover intention. However, Policies and Procedures in organizations did contribute to employee satisfaction that can influence turnover intention. Employees were more satisfied with organizations that had clear policies and procedures on religiosity, provide space for prayer or meditation, allow employees to take time off for prayers, respect the employees' freedom to display religious decorations in the workplace and dress according to their religious beliefs. As a conclusion, the researchers also found that the religious calling, even if it was not a predictor of turnover intention, was nevertheless noteworthy.
\end{abstract}

Index Terms-Religiosity calling, turnover intentions, employee satisfaction.

\section{INTRODUCTION}

In Malaysia, the statistics of turnover cases are considerably high. According to statistics from the Labour and Human Resource website, in 2009 alone, there were 17,286 cases reported ranging from different sectors such as Agriculture, Hunting and Forestry, Utilities, Hotel and Restaurant, Public Administration, Education, etc. The exit of important and valuable human resources from the organizations leads to the loss of tacit knowledge possessed by the leaving employees, and also as a huge effect on the cost of operations due to high cost of filling vacant positions [1]. Turnover also contributes to personal costs of employee in the form of lost benefits, friendship and sometime a disruption of the family.

In the Malaysian context, studies show that job satisfaction is one of the factors or reasons for employee intention to leave the organization [2]-[6]. Employee job satisfaction is one of the most studied employee work attitudes in the organizational behaviour literature. Employee work attitudes are important because it has been linked to several important work behaviours that can affect the firm's bottom line, such

Menuscript received September 16, 2013; revised November 17, 2013.

The authors are with the Faculty of Business Management, University Teknologi MARA, 42300 Puncak Alam, Selangor, Malaysia (email: drnarehan@puncakalam.uitm.edu.my). as absenteeism, turnover, and service quality [7].

Ghazzawi and Smith [8] stated that, under certain conditions, religious faith is a strengthening of, or substitution for job satisfaction. They found that a religious worker may be dissatisfied with his/her job, but still be as productive as a satisfied worker. Although the results are mixed, some studies have found a correlation between and job satisfaction. Furthermore, study conducted by [9] on the influence of creative organizational climate on learning organization among employees in private organizations also found a strong relationship between job satisfaction and turnover intention. However, very limited studies investigated the influence of religious belief towards employee's satisfaction. A large number of studies have focused on the concept spirituality rather than religiosity for obvious reasons [10] whereby religion is expected to generate negative findings due to the misconception of the religion itself.

Most of the employees leave the organization because they were not given the opportunity to practice their religious belief such as lack facilities to perform prayers and discrimination due to attire that represent their religion. This has send the signal that religiosity in the workplace is expected to become an important factor as more employees consider their job as religious calling. Therefore, when employees consider their job as a religious calling which also means religious obligation, it is expected that this factor can contribute to increased job satisfaction, organizational commitment and reduce in turnover intention. In order to make the findings of this study meaningful, a set of measuring instrument or defining job as a religious calling must be developed.

\section{LITERATURE REVIEW}

Employees are not machine - they are entire persons with racial, gender, and spiritual dimensions [11]. Employee satisfaction is a term coined to understand the factors that motivate employees. In an effort to better understand the factors which motivate employees, Frederick Herzberg [12] performed interviews with employees to determine what aspect of their job they like and what aspect caused displeasure to them.

Herzberg theory of needs is divided into two that are 1) the need for psychological growth or motivating factors; 2) the need to avoid pain or hygiene factors. This theory claims that motivating factors like achievement and advancement are positive elements that contribute towards job satisfaction and motivation. Hygiene factors such as company or organizational policies, quality of supervision, working 
condition, salary, relationship with peers and subordinates, status and security are negative elements that could cause dissatisfaction in work. The extent to which an employee is allowed and encouraged to express him or herself through spirituality is an indication, a tool of measurement, for his or her emotional and psychological state [13].

Job satisfaction and job dissatisfaction are totally separate dimensions. A major influence on an employee's job satisfaction or dissatisfaction is the subtle permission on the part of the employer to be an entire, whole person at work, not to discriminate their gender, or ethnicity or religion [14]. The desire to be an entire persona at work is strong among the millennial generation [15] that has affects the job satisfaction or dissatisfaction of many employees [16] and created a growing interest in the effects of spirituality and religion in the workplace [17]. Studies have consistently reported that job satisfaction is one of the factors or reasons for employee intention to leave the organization [4] ; job satisfaction accounted for a larger variance in turnover intentions than job characteristics . In addition to that, Mosadeghrad, Ferlie \& Rosenberg [18] also found that although hospital employees are moderately satisfied with their jobs, they are still committed to their organization. This shows that employee's job satisfaction and organizational commitment were closely inter-related and correlated with turnover intention. Employees who experience job satisfaction are more likely to be productive and stay on the job [3].

The desire to integrate one entire self at work is not limited to demographic or age group, rather it affects the job satisfaction or dissatisfaction of many employees. Hutson [19] stated that there is a strong spiritual reality to peoples' lives. The concept of religiosity and spirituality has gain attention among researchers of organizational studies and management. However, the concept is largely defined by the individual concerned [20], thus its value as management variable remains in debate [17]. Fairholm, [21] stated that religion and spirituality are evident and persuasive in the ethical attitudes, moral reasoning, and management behavior of many public administrations. Further study by Pargament and Mahoney [22] write that religion can give depth and discipline to spirituality, making it more secure, stable, and appropriate. However spirituality is not and should not be entirely rooted in religion, for several reasons. Spirituality is distinct from but related to religion [23]. Though spirituality in the workplace has been extensively researched, religion in the workplace has had much less study [24]. Religion is a set of values, doctrines, and principles that provide an ethical and moral framework for understanding, motivation, and behavior[25]. Nonetheless, the benefit of spirituality in the workplace have stated that individuals and organization who perceived themselves as more " spiritual" are more creative, productive, and adaptive[26] . Productivity, moral and employees satisfaction have also been seen to increase when spirituality is part to the workplace. Some dangers associated with ignoring the satisfaction in the workplace include people falling short of their potential, decrease creativity, fear, and resistance to change as well as high turnover, burnout and absenteeism [27].

Turnover refers basically to permanent quitting or getting separation from job [28] while Brigham, Castro and Shepherd
[29] defines turnover as intention to exit. This particular act of exiting from an organization is detrimental because it is related to direct and indirect costs; it affects morale, productivity, reputation, and survival of the organizations [30]. Recent study by [31] stated that staff retention is one of the greatest human resource challenges faced by organizations today. The costs of high staff turnover is substantial as it involve not only the direct financial costs of replacing staff but also other repercussions such as the potential loss of key skills, knowledge and experience, disruption to operations and the negative effect on workforce morale.

\section{Dimension OF RELIGIOSITY IN THE WORKPLACE}

The dimensions of religiosity in the workplace are according to the findings from the interview; Policies and Procedures, Job as a Religious Calling and Leadership Style.

\section{A. Policies and Procedures}

The need for effective workplace policies and procedures has never been more important in today's changing workplace. For example the recent changes to industrial relations legislation and the move to a national system have resulted in the emergence of workplace issues of discrimination, workplace rights, and unfair dismissals that should be covered by effective policies [32].

Society for Human Resource Management Research (SHRM): Religion in the Workplace Survey [33], found that, more than one-third of respondents indicated there are more religions represented in their workforces compared to five years ago and less than one third of respondents' organization have an official written policy regarding religious diversity.

Majority of respondents indicated their organizations have written policy regarding religious harassment; most frequently communicated through the employee handbook. In addition, Ponnu and Chuah [31]conducted a study on organizational commitment, organizational justice and employee turnover in Malaysia. The finding stated that when employee's perception of procedural was high, their commitment was also high which lead to less in turnover intention. Employees will be committed to their employer if they perceive higher fairness (policies and procedures) in the organization.

Moreover, Intel's human rights principal [34] documented human rights issues that focus on a few religion practices. Their issues are on diversity which they applying laws that provide equal employment opportunity for all employees regardless of their race, skin, colour, religion, gender, etc; and on harassments prohibition. Intel's is committed to provide a workplace free of religion harassment, sexual and etc. All employees are treated with dignity and respect.

\section{B. Leadership Style}

The context of leadership has changed over the years and is now in a state of rapid change due to technological advances and increasing of global competition [35]. Employees diversity in the workplace alerting the need to have a spiritual leadership in the organization. Fry [20] argued that spiritual leader deploy spiritual resources in social contexts; they follow God's will by obeying divine or 
higher laws (values) in their daily lives. Several studies by Barton and Ford [36]; Sparks [37] emphasis that criteria for a spiritual leader include confidence in and acknowledgement of God, obedience to God, adherence to God's path and motivation based on the love of God.

There are two approaches in leadership. The first is the trait approach or transactional and another one is the charismatic/transformational leadership approach [38]. Transformational leader is generously accepted and obeyed by followers due to their strong need for power and high self-confidence. Transactional leader on the other hand is characterized by contingent reward and management-by-exception. In organizational studies, transformational leadership is used more often.

Study conducted by Sarver [39] focus on to determine the relationship between religiosity and spirituality on transformational leadership and also the influences of religiosity and spiritual beliefs on the workplace and the workplace practices. The findings were no relationship between religiosity and spirituality of managers and their employees with transformational leadership characteristics of managers. In spite, transformational leadership was related to other variables such as type of manager, job enjoyment by manager and employees as well as issues relating to trust between managers and employees.

Dent, Higgins and Wharff [40] conducted qualitative review of 87 articles and proposed that there is a clear consistency between spiritual values and practices and leadership effectiveness. Reave [41] done a review and found that values have been considered spiritual ideals such as integrity, honesty, and humility, have an effect on leadership success. Further research conducted by Ayranci [42] examines the relationship between spiritual leadership and issues of spirituality and religiosity among Turkish managers found that spiritual leadership of Turkish managers depends on their wisdom and unselfishness and their spirituality is comprised of their approach to immateriality and their spiritual awareness.

\section{Religious Calling}

The term 'Religious Calling' has no exact definition and varies from one study to another. Mosadeghrad, Ferlie \& Rosenberg [18] cited that in the Judeo-Christian perspective, a calling might be defined as "the belief that one's tasks are inspired by a spiritual, rather than maternity entity". On the other hand, the Islamic definition for work as religious calling is seen in various verses of Al-Quran. One example is "and that man can have nothing but what he does (good or bad). And that his deeds will be seen. Then he will be recompensed with a full and best recompense" [43].

All the verses stress the need for work and action by human beings. The work, therefore, is regarded not only as a right but a duty and an obligation. The key component is the belief that one has not ended up in a job because of random chance or because of one's own design; but rather, an individual believes that he or she has been 'put' in their job to serve a higher purpose [44].

One study conducted by Roundy [45] has a different finding compared to the SHRM findings. Roundy hypothesized that the relationship between religious calling and work satisfaction is moderated by the third factor which is organizational spiritually; organization that are "spiritual" will strengthen the relationship while for non-spiritual organizations, the relationship will be either attenuated or negated. The study suggests that if employers wanted to increase the job satisfaction; employees, both religious and not-religious should strive to increase spiritually of their organization.

Morgan [46] found that the "traditional wall separating faith form work" seems to be crumbling at an accelerated rate causing “today's workers to be far more prone to do what in the past was unthinkable: want to practice religion while at work". These trends suggest that, since significant number of people consider religion to be an important aspect of their lives, and since increase in number of employees combining between their religion and their work, some understanding of how religious beliefs influences work preferences and outcomes is certainly desirable [23]. Satisfying the requirements of one's religion through one's work may cause an individual to receive increased satisfaction from the feeling that they are successfully integrating their religious values, or their religious lives, into their work.

Another link between religious callings and job satisfaction is that individuals who believe their work is a religious calling may feel as if their jobs possess an importance or "weightiness" that non-religious-calling employment does not possess. Bokemeier and Lacy [47]found that, the more purpose individuals find in their work the greater their work satisfaction.

\section{DEFINITION OF INTENTION TO LEAVE}

It is sufficient to say that turnover has been a controversial issue since its effects have been inconsistent depending on the context of the organization [23]. In a study among staff in Telecom Malaysia [3], it was found that there is a relationship between job characteristics and job satisfaction on turnover intention with job satisfaction contribute to larger variance to intentions than job characteristic. Study by Gaan [3] shows that relationship between organizational commitment and turnover is consistent with the Samad [5] study. It's also found that employees' job satisfaction and organizational commitment were closely inter-related and correlated with turnover intention.

Job dissatisfaction has been found to be strong and consistent predictor of intention to leave as well as turnover [6]. Research has shown that increased commitments improves employees' job satisfaction, motivation, performance, and creativeness, and reduce absenteeism and turnover [2].

\section{Research Methodology}

\section{A. Research Design}

The study took qualitative approach in identifying dimensions of religiosity in the workplace. Interview with 15 employees result that Policies and Procedures, Religious Calling and Leadership Style to be the factor of religousity. The second approach used a quantitative research method to identify the correlations between religiosity and turnover 
intention. The purpose of using correlation research design was to measure the degree of relationship between variables under study [48].

\section{B. Population}

The sampling frame was the employees currently working at hypermarkets (Carefour, Giant and Tesco) in Klang Valley. In this study, the population was all supermarkets in Klang Valley, Malaysia coming to a total of 122 hypermarkets.

\section{Sample Size}

Multivariate research (including multiple regression analyses), requires the sample size to be several times (preferably 15 times or more) as large as the number of variables in the study. Researcher determined the sample size by using 25 observations for each variable in the study. As the number of variables is 5 , the total sample size comprised of 125 employees from the hypermarkets. Table I below shows the employees sample size.

TABLE I: EMPLOYEES SAMPLE SIZE

\begin{tabular}{llc}
\hline \hline No. & Hypermarkets & No. of Employees \\
\hline 1 & Carefour & 55 \\
2 & Tesco & 40 \\
3 & Giant & 30 \\
\hline \hline
\end{tabular}

\section{Sampling Technique}

Elements for this study consist of employees working in hypermarket around Klang Valley. The researchers used non-probability sampling technique; convenience sampling where the elements in the population do not have any probabilities to be chosen as sample subjects [49].

\section{E. Measurement}

The measurement developed by the researchers according to the findings. The dimensions of job satisfaction are Policies and Procedures, Job as a Religious Calling and Leadership Style. Table II illustrates the dimension of Policies and Procedures was adapted from SHRM [50]; dimension of Religious Calling was adapted from Oler (2005); Leadership Style dimension was adapted from Sarver [39] and Turnover Intention dimension was adapted from Pare \& Tremblay [51] as shown in Table III.

TABLE II: ELEMENTS OF RELIGIOSITY CALLING

\begin{tabular}{lc}
\multicolumn{1}{c}{ Elements } & No. of Items \\
\hline \hline Policies and Procedures & 7 \\
Religious Calling & 12 \\
Leadership Style & 5 \\
\hline \hline
\end{tabular}

TABLE III: ELEMENTS TURNOVER INTENTION

\begin{tabular}{lc}
\hline \hline Elements & No. of Items \\
\hline Turnover Intention & 5 \\
\hline \hline
\end{tabular}

\section{FINDINGS}

\section{A. Normality Test}

The summary of initials normality tests below (Table IV) shows that the skewness and kurtosis values for research variables are less than 2 and 3 respectively although there were several outliers in the boxplot.

The normality tests was conducted after the deletion of items are presented below (Table V) shows that skewness and

TABLE IV: NORMALITY TEST

\begin{tabular}{lllc}
\hline \hline & Variable & Skewness & Kurtosis \\
\hline Independent & Policies and Procedures & -.552 & -1.002 \\
& Job as a Religious Calling & -.033 & -0.821 \\
& Leadership Style & -1.776 & $\mathbf{4 . 9 9 5}$ \\
Dependent & Turnover Intention & -.274 & -0.325 \\
\hline \hline
\end{tabular}

TABLE V: NORMALITY TEST AFTER DELETION OF ITEMS

\begin{tabular}{lllc}
\hline \hline & Variable & Skewness & Kurtosis \\
\hline Independent & Policies and Procedures & -.522 & -1.002 \\
& Job as a Religious & -.450 & -0.655 \\
& Leadership Style & -1.776 & $\mathbf{4 . 9 9 5}$ \\
Dependent & Turnover Intention & -.219 & -0.166 \\
\hline \hline
\end{tabular}

\section{B. Reliability Test}

The initial reliability test (Table VI) shows that the Cronbach's alpha for overall variables was .691. Independent variables reliability tests are in the range of 696 to 889 indicate that the measure has high internal consistency and stability. Dependent variable reliability coefficients are moderate with Cronbach's alpha at .679.

Reliability test after deletion of items (Table VII) decreased the Cronbach's alpha for overall variable from .691 to .625. However, the independent variables reliability tests increased to the range of .807 to .889 ; thus indicate that the measure has high internal consistency and stability. The analysis also produces moderate coefficients for the dependent variable with .616.

Hence, based on the reliability analysis, the measures used in the study are reliable, suggesting its readiness for further analyses.

TABLE VI: RELIABILITY TEST

\begin{tabular}{llcc}
\hline \hline \multicolumn{1}{c}{ Dimension/Variable } & No. of items & $N=125$ \\
\hline \multirow{3}{*}{ Independent } & Overall & 71 & 0.691 \\
& Policies and Procedures & 12 & 0.696 \\
& Job as a Religious Calling & 5 & 0.686 \\
\multirow{3}{*}{ Dependent } & Leadership Style & 7 & 0.889 \\
& Turnover Intention & & 0.679 \\
\hline \hline
\end{tabular}

TABLE VII: RELIABILITY TEST AFTER DELETION OF ITEMS

\begin{tabular}{cccc}
\hline \hline \multirow{3}{*}{ Dimension/Variable } & No. of items & $N=125$ \\
\hline \multirow{5}{*}{ Dependentent } & Overall & 24 & 0.625 \\
& Policies and Procedures & 4 & 0.857 \\
& Job as a Religious Calling & 9 & 0.807 \\
& Leadership Style & 5 & $\mathbf{0 . 8 8 9}$ \\
& Turnover Intention & 6 & 0.616 \\
\hline \hline
\end{tabular}

\section{Factor Analysis}

Factor analyses were performed independently for each scale concerning Policies and Procedures, Job as a Religious Calling and Leadership Style. Only items with a loading of .50 or greater on one factor were considered. In the case of cross-loadings, an item that loads at .32 or higher on two or more factors or the difference between and among factors is less than .10, the items were considered for deletion. 
The clean factors were then interpreted or named by examining the largest values linking the factors to the items in the rotated factor matrix.

Therefore, 3 items from variable Policies and Procedures (PP4, PP6 and PP7) and 3 items from Job as a Religious Calling (RC2, RC5 and RC11) were deleted.

\section{ACKNOWLEDGEMENT}

This research was funded by the Fundamental Research Grant Scheme and Universiti Teknologi MARA (UiTM), Malaysia.

\section{REFERENCES}

[1] T. A. Wright and D. G. Bonett, "Job satisfaction and psychological well-being as nonadditive predictors of workplace turnover," Journal of Management, vol. 33, pp. 141-160, 2007.

[2] J. Coninck and D. Bachmann, "An analysis of turnover among retail buyers," Journal of Business Research, vol. 58, pp. 874-882, 2005.

[3] M. Voon, M. Lo, K. Ngui, and N. Ayob, "The influence of leadership styles on employee job satisfaction in public sector organization Malaysia," International Journal of Business, Management and Social Sciences, vol. 2, pp. 24-32, 2011.

[4] J. L. Price, "Reflections on the determinants of voluntary turnover," International Journal of Manpower, vol. 22, pp. 600-624, 2001.

[5] S. Samad, "The contribution of demographic variables: job characteristics and job satisfaction on turnover intentions," Journal of International Management Studies, vol. 1, pp. 219-231, 2006.

[6] J. Sourdif, "Predictors of nurses' intent to stay at work in a university health center," Nursing and Health Sciences, vol. 6, pp. 59-68, 2004.

[7] R. L. Snipes, S. L. Oswald, M. LaTour, and A. A. Armenakis, "The effects of specific job satisfaction facets on customer perceptions of service quality: an employee-level analysis," Journal of Business Research, vol. 58, pp. 1330-1339, 2005.

[8] I. Ghazzawi and Y. Smith, "Crafting the whole employee: job satisfaction, job commitment, and faith-a new conceptual framework and research agenda," The Business Review, vol. 12, pp. 300-309, 2009.

[9] M. Said, S. Sudin, and I. Ali, "Measuring the level of customer satisfaction among employees of a human resource division," Advances in global Business Research, pp. 187, 2006.

[10] P. C. Hill and K. I. Pargament, "Advances in the conceptualization and measurement of religion and spirituality: Implications for physical and mental health research," 2008.

[11] A. E. Ghazzawi, "Navigating the Stroke Rehabilitation System: A Family Caregiver's Perspective," University of Ottawa, 2012.

[12] F. Herzberg, "Motivation-hygiene theory," Correlates of Mental Health: An Examination of Motivational Inversion in a Clinical Population, New York: Wiley, pp. 61, 2005.

[13] E. Marschke, R. Preziosi, and W. Harrington, "Professionals and executives support a relationship between organizational commitmen and spirituality in the workplace," Journal of Business and Economics Research (JBER), vol. 7, 2011.

[14] P. Heim, S. Murphy, and S. K. Golant, In the Company of Women: Turning Workplace Conflict into Powerful Alliances, JP Tarcher/Putnam, 2001.

[15] A. C. Brooks, Gross National Happiness: Why Happiness Matters for America--and How We Can Get More of It, Basic Books (AZ), 2008.

[16] A. P. Brief, Attitudes in and Around Organizations, vol. 9, 1998

[17] R. D. Duffy, "Spirituality, religion, and career development: Current status and future directions," The Career Development Quarterly, vol. 55, pp. 52-63, 2006.

[18] A. M. Mosadeghrad, E. Ferlie, and D. Rosenberg, "A study of the relationship between job satisfaction, organizational commitment and turnover intention among hospital employees," Health Services Management Research, vol. 21, pp. 211-227, 2008.

[19] S. Hutson, "Why religion matters: The fate of the human spirit in an age of disbelief," New York: Harper and Row, 2000.

[20] L. W. Fry, "Toward a theory of spiritual leadership," The Leadership Quarterly, vol. 14, pp. 693-727, 2003.

[21] G. W. Fairholm, Mastering Inner Leadership, Greenwood Publishing Group, 2001

[22] K. I. Pargament and A. Mahoney, "Spirituality: discovering and conserving the sacred," 2002.
[23] S. M. King, "Religion, spirituality, and the workplace: challenges for public administration," Public Administration Review, vol. 67, pp. 103-114, 2007.

[24] A. R. Bergen, Power Systems Analysis, 2/E, Pearson Education India, 2009.

[25] S. M. King, "Toward a new administrative ethic: An understanding and application of the Judeo-Christian tradition to administrative issues," Public Integrity, vol. 2, pp. 17-28, 2000.

[26] I. I. Mitroff, I. Mitroff, and E. A. Denton, A Spiritual Audit of Corporate America: A Hard Look at Spirituality, Religion, and Values in the Workplace, Jossey-Bass, vol. 140, 1999.

[27] J. C. G. Zamor, "Workplace spirituality and organizational performance," Public Administration Review, vol. 63, pp. 355-363, 2003.

[28] R. Zafar, M. Altaf, M. M. M. Bagram, and H. Hussain, "Religiosity, as determinant of turnover intention: An exploratory study," The Journal of Commerce, vol. 4, no. 4, pp. 1-8.

[29] K. H. Brigham, J. O. D. Castro, and D. A. Shepherd, "A personorganization fit model of owner - managers' cognitive style and organizational demands," Entrepreneurship Theory and Practice, vol. 31, pp. 29-51, 2007.

[30] T. R. Hinkin and J. B. Tracey, "The cost of turnover: Putting a price on the learning curve," The Cornell Hotel and Restaurant Administration Quarterly, vol. 41, pp. 14-4, 2000.

[31] C. Ponnu and C. Chuah, "Organizational commitment, organizational justice and employee turnover in Malaysia," Afr. J. Bus. Manage, vol. 4, pp. 2676-2692, 2010.

[32] S. Bendix, Industrial Relations in South Africa, Juta and Company Ltd, 2010.

[33] D. A. Hicks, Religion and the Workplace: Pluralism, Spirituality, Leadership, Cambridge University Press, 2003.

[34] L. Hunt, Inventing Human Rights: A history, WW Norton and Company, 2008.

[35] J. G. Clawson, Level Three Leadership, Prentice Hall, 2002.

[36] R. H. Barton, Strengthening the Soul of Your Leadership: Seeking God in the Crucible of Ministry, Inter Varsity Press, 2012.

[37] B. N. Sparks, Journey-A Traveller's Guide to Leadership, Basil Sparks, 2008.

[38] J. Schepers, M. Wetzels, and K. de Ruyter, "Leadership styles in technology acceptance: do followers practice what leaders preach?" Managing Service Quality, vol. 15, pp. 496-508, 2005.

[39] A. N. Sarver, "The effect of religiosity and spirituality on transformational leadership characteristics of hospital food and nutrition managers," Brigham Young University, 2005.

[40] E. B. Dent, M. E. Higgins, and D. M. Wharff, "Spirituality and leadership: An empirical review of definitions, distinctions, and embedded assumptions," The Leadership Quarterly, vol. 16, pp. 625-653, 2005.

[41] L. Reave, "Spiritual values and practices related to leadership effectiveness," The Leadership Quarterly, vol. 16, pp. 655-687, 2005.

[42] E. Ayranci and F. Semercioz, "The relationship between spiritual leadership and issues of spirituality and religiosity: A study of top Turkish managers," International Journal of Business and Management, vol. 6, pp. 136, 2011.

[43] M. Q. Shihab, Tafsir al-Mishbāh: Pesan, Kesan, Dan Keserasian Al-Qur'an, Lentera Hati, 2006.

[44] J. C. Davidson and D. P. Caddell, "Religion and the meaning of work," Journal for the Scientific Study of Religion, pp. 135-147, 1994.

[45] P. T. Roundy, “'Every man's work shall be made manifest': Religious Callings in the Age of Organizational Spirituality," Journal for the Renewal of Religion and Theology, vol. 5, 2009.

[46] J. F. Morgan, "Perhaps oil and water can mix: The Workplace Religious Freedom Act of 2005," Employee Relations Law Journal, vol. 31, pp. 27-47, 2005.

[47] J. L. Bokemeier and W. B. Lacy, "Job values, rewards, and work conditions as factors in job satisfaction among men and women," The Sociological Quarterly, vol. 28, pp. 189-204, 1987.

[48] R. E. Hall, "Employment fluctuations with equilibrium wage stickiness," American Economic Review, pp. 50-65, 2005.

[49] U. Sekaran and R. Bougie, Research Methods for Business: A Skill Building Approach, Wiley, London, 2010.

[50] M. Parks, "2006 workplace romance," Society for Human Resource Management, Alexandria, VA, 2006.

[51] G. Paré, M. Tremblay, and P. Lalonde, "The impact of human resources practices on IT personnel commitment, citizenship behaviors, and turnover intentions," in Proc. the Twenty First International Conference on Information Systems, 2000, pp. 461-466. 
Narehan Hassan was born in Klang, Malaysia. She holds a Ph.D. in in Education (Student Development) from Southern Illinois University, United States of America. She held many positions including Confidential Secretary, Tutor, and Training Manager in Malaysia before embarking on academic discipline and obtained all of her tertiary degrees from American universities. She has more than 25 years of teaching experience in adult education. Right now, she is an Associate Professor at the Center for Applied Management, Faculty of Business Management, University Teknologi MARA, Malaysia.

Azlyantiny Mohammad is a lecturer at Universiti Teknologi MARA, Shah Alam. She obtained her Master in Office Systems and Management and Bachelor in Office Systems Management (Hons), Universiti Teknologi MARA, Shah Alam. Her areas of interest include Human Resource Management and Communication.

Feridah Mohd. Nadzar is an associate professor at the Center for Applied Management, Universiti Teknologi MARA and holds a PhD in Education from the University of Malaya. She has 30 years of teaching adults. She obtained both her bachelor's and master's degrees from American universities. Her areas of interest include Religious Studies, Human Resource Management and Office Management.
Rozilah Abdul Aziz was born in Kuala Lumpur, Malaysia. She is a postgraduate student at Universiti Teknologi MARA, Shah Alam and currently conducting a doctoral research in the field of Organizational Communication. Rozilah obtained her MSc. in Corporate Communication from Universiti Putra Malaysia (UPM) and BBA in Business Administration from Western Michigan University, USA. She is currently a senior lecturer at the Faculty of Business Management in Universiti Teknologi MARA, Shah Alam. Her areas of interest include Organizational Communication, Human Communication, Organizational Behavior and Personality Development.

Sharrifah Ali was born in Kuala Terengganu, Malaysia. She earned both her Bachelor's and Master's Degree in the area of business education from Wilmington College and the University of Pittsburgh, USA respectively. She is currently a senior lecturer at the Center for Applied Management, Faculty of Business Management, Universiti Teknologi MARA, Malaysia. At the moment, she is in the midst of completing her doctoral thesis in the area of Training Transfer and Motivation. 